\title{
Avansert premissmodulering
}

\author{
Akademiske foredrag kan av og til bli så høyttravende og uforståelige at man av og til lurer \\ på om dette er genialt eller det rene og skjære sprøyt. Kirurgen Nils Øhre Nilsen tok i sin tid \\ fatt på dette problemet.
}

Vi ser oftere og oftere, både i det politiske liv og i samfunnsdebatten ellers, at premisser for en konklusjon kan forandres etter behov. Har man behov for en bestemt konklusjon, må følgelig premissene tilpasses konklusjonen, eller med et finere ord, moduleres. Her var kirurg Nils Øhre Nilsen langt forut for sin tid da han basert på et juleforedrag på Rikshospitalet i 1968 skrev en artikkel i Terapeutiske Fremskritt om det han kalte premissmodulering. Artikkelen er i seg selv liten, skrevet i et høytidelig språk, og man skal lese flere sider før den bitende ironien blir klar for leseren. Han har gjort norsk akademisk verden en stor tjeneste ved å skrive denne artikkelen.

Nils Øhre Nilsen (1930-98) var cand.med. fra Oslo i 1956 og hadde hatt tjeneste ved forskjellige kirurgiske avdelinger før han kom til Rikshospitalet. Her arbeidet han lenge på Kirurgisk avdeling A, på Institutt for patologi (daværende Autopsiavdelingen) og på det nystiftede Institutt for kirurgisk forskning. Blant annet viste han hvordan kortvarig temperaturøkning kunne føre til misdannelser hos kyllingfostre. Han skrev doktorgradsavhandling om dette emnet i Uppsala og arbeidet senere som kirurg på forskjellige sykehus i Norge.

Artikkelen, som er gjengitt nedenfor, vakte i sin tid oppsikt. Konklusjonen var at premissmodulering foregår i flere dimensjoner, med forskjellige elementer av kryssende hensyn som griper inn i hverandre. Mange moret seg, noen ergret seg, og enkelte gikk så langt i ergrelsen at de kalte han for «Røre Nilsen». Men det skyldtes nok ren og skjær misunnelse. Artikkelen egner seg godt til høytlesning for viderekomne akademikere, men kan gi uro hos småbarn.

\section{Ole Didrik Lærum}

ole.laerum@gades.uib.no

Ole Didrik Lærum er professor (adj.) ved Københavns Universitet og professor emeritus ved Universitetet i Bergen.

\section{Nyere metoder til behandling av flerdimensjonal plastisk premissproblematikk ved hjelp av differensierte EDB-systemer og bruk av forskjellige former for «short-cuts»}

\author{
Av Nils Øhre Nilsen
}

Foredrag ved julemøte i Institutt for Eksperimentell Enzymkirurgi, Rikshospitalet, 12/12-68

Problemer i forbindelse med premisser og konklusjoner er meget gamle og har sin opprinnelse mange hundre millioner år tilbake i tiden. Den første figuren (fig. 1) viser skjematisk den historiske bakgrunn for den situasjon vi befinner oss i i dag. Bildet er en rekonstruksjon av en halsesyk dinosaur $i$ ferd med å fortære en Dekadin. Som kjent er nå forholdene det at dinosaurene døde ut, mens halsesyke fortsatte med å være en svøpe for en rekke dyrearter på forskjellig differensieringsnivå. Dette til tross for at man med sikkerhet vet at Dekadin fantes i naturlige forekomster og i aktiv form.

Det har vært hevdet at Dekadin ikke skulle være virksomt, og at dette således skulle være en medvirkende årsak til at dinosaurene forsvant. Dette er imidlertid blitt energisk imøtegått fra arabisk hold der man hadde stor glede av stoffet i kavaleriet under Sinaifelttoget. Når resultatene av felttoget allikevel ble som de ble, bekrefter det bare det komplekse omfang av disse problemer.
I British Museum finnes en annen rekonstruksjon med et enda dypere perspektiv og mer emosjonelt preg. Man kan der tydelig fornemme det vemodige smilet hos denne dinosaur ved å ha blitt fossilt preparat, og dette til tross for det ganske enestående å være utstyrt med hele åtte fortenner.

Det nyeste og mest dyptpløyende bidrag på premissproblematikkens område er et verk som nettopp er utkommet fra Darwin 
Figur fjernet av hensyn til opphavsrett. Se artikkelens utgave på papir for fullstendig versjon
Figur fjernet av hensyn til opphavsrett. Se artikkelens utgave på papir for fullstendig versjon

Fig. 2. Premiss-dissosiasjons-angina.

Fig. 1. Dinosaur, Diplodocus, med hal sesyke umiddelbart for Dekadin. Juraperioden midtre del, ca. 150 millioner år siden. Rekonstruksjon.

Figur fjernet av hensyn til opphavsrett. Se artikkelens utgave på papir for fullstendig versjon

\section{Fig. 3. Kardinalproblemet ved premiss- modulering - binding til objektive hensyn.}

P. Erlandsens penn. Blant meget annet skriver han også følgende:

«Hvis alle premisser i en korrekt slutning står i indikativ, må også slutningens konklusjon stå i indikativ. Hvis alle premisser i en korrekt slutning står i imperativ, kan kon-
Figur fjernet av hensyn til opphavsrett. Se artikkelens utgave på papir for fullstendig versjon

Fig. 4. «Compremisse naturelle». Underordnet sykehuslege modulert over en 15-årsperiode. Optimumsresultat.

klusjonen i samme slutning ikke stå i indikativ. I deskreptive premisser kan inngå en tankenødvendig slutning med normativ konklusjon, forutsatt at det totale antall premisser som inngår i samme slutning er større enn n. (Forutsettes bl.a. $\mathrm{n}=$ tall større enn 0 , følger «tertium non datur» og kontra- diksjonsprinsippet.) - Innstillingers potensielle selvverifikasjon bør ikke overskygge idealmodellen helt.»

Den siste formuleringen er spesielt utformet med tanke på situasjoner som kan oppstå f.eks. ved tilsetting av sykehusleger.

Verket hvor sitatet er hentet fra bærer som tittel et sitat fra Stalin, noen ord han skal ha uttalt da de kom for å hente ham til balsamering: «Bevare meg vel.»

Det er mange grunner til å anta at hverken Stalin, Beria eller Malenkov trakk de samme konklusjoner av dette utsagn. Det representerer således et eksempel på premissdissosiasjon. Vi føler alle en dyp takknemlighet overfor sovjet-russerne og deres evne til stadighet å kunne bringe nye eksempler av denne type, selv om en del kan være nokså tungt å svelge. (Fig. 2.)

Et sentralt begrep som logisk følger av fenomenet premissdissosiasjon er den såkalte premissmodulering. Denne prosessen har forløpet i generelle former blant mennesker i uminnelige tider, men også på dette område har det foregått en spesialisering i de senere år.

Den mest alminnelige metoden, den såkalte naturmetoden, som også krever minst med hensyn til spesielle forutsetninger, går $\mathrm{i}$ korthet ut på å anta at mave-tarm-traktus er en sjøorm. Derved elimineres enhver tendens til nausea. Ved dyp konsentrasjon kan man så uansett graden av diastase i den foreliggende premissdissosiasjon lykkes $\mathrm{i}$ å gjøre gode miner til slett spill. Hvis man bare passer på ikke å være altfor bundet av objektive hensyn (fig. 3), kan man drive det langt bare ved hjelp av denne opprinnelige metoden. Fig. 4 viser skjematisk en underordnet sykehuslege med ca. 15 års tjeneste modulert etter det optimale hensiktsmessighets prinsipp. Dette klassiske bilde er blitt betegnet som «Compremisse naturelle» .

I det følgende vil bli behandlet noen hyppig forekommende former for premissmodulering fra det daglige liv. I første rekke har
Figur fjernet av hensyn til opphavsrett. Se artikkelens utgave på papir for fullstendig versjon
Figur fjernet av hensyn til opphavsrett. Se artikkelens utgave på papir for fullstendig versjon 
vi her slike former som er betinget i og sprunget ut av forholdet mellom individer av motsatt kjønn. Slike premissmodulatoriske prosesser kan skjematisk tenkes å foregå ved hjelp av rotasjonsprinsippet fra søndag til lørdag, med det minimumsformål å oppnå temporær konjugasjon. Dette eksemplet ligger nær opp til det gynekologiske område, hvor det samme prinsippet kan illustreres ved hjelp av en ubalansert trebladet rotor i strategisk posisjon (fig. 5). Som figuren antyder er det mange forhold å sette finger på i denne forbindelse. En finger ferdig til å settes på er også vist på figuren.

Premissmodulatoriske problemkomplekser kan ofte gjøre seg sterkt gjeldende i praktiske, kliniske situasjoner. Enda viktigere er imidlertid behovet for nøyaktige og presist formulerte motiver etter at en større eksperimentell, vitenskapelig undersøkelser er gjennomført: Om ikke før, så vil det når man skal legge siste hånd på manuskriptet, ofte være ønskelig å formulere en klar problemstilling og så skrive innledningen. At dette ofte kan by på store vanskeligheter med bare den gamle naturmetoden til hjelp fremgår av figur $6 \mathrm{og} 7$. I visse tilfeller oppstår på grunnlag av en slik situasjon alvorligere indre forstyrrelser hos vedkommende vitenskapsmann. Det kan dreie seg om mentale og sentralnervøse kompleksdannelser som er betegnet som data-perseverasjonsmonomani.

Ved utviklingen av forskjellige EDB-systemer har det imidlertid i de senere år åpnet seg muligheter for å overlate grovarbeidet med justering av premissdissosiasjoner til en computer, en såkalt premissmodulator. En modell i kunstnerisk utforming var høsten 1968 utstilt på Statens Høstutstilling under mottoet «Monument over en automobi1». En prototyp er nettopp ferdig fremstilt ved Sentralinstituttet for Industriell Forskning og står klar til prøvekjøring. Med hensyn til det eksperimentelle grunnlag for denne nye maskin kan det nevnes at de første preliminære forsøk ble foretatt allerede for mange år siden. Et av de aller tidligste eksperimenter ble foretatt med en kubisk kasselignende konstruksjon isolert med flere lag indifferent materiale, for å hindre interferens gjennom miljøpåvirkning. Ved dyp konsentrasjon kunne man så vel anbrakt inne i kassen prøve å ruge ut de best tilpassede premisser.

Ved ytterligere fordypelse i stoffet er det senere så foretatt en strukturanalyse i samarbeid med både mer og mindre velvillig innstilte kolleger ved Rikshospitalet. Dette har ført til erkjennelsen av at premissmodulering foregår i flere dimensjoner. På modell kan det vises hvordan de forskjellige elementer i form av kryssende hensyn griper inn i hverandre.
I tiden ved Rikshospitalet ble det også muligheter for forsøk med raffinert apparatur i form av rugemaskiner og kyllinger som forsøksmateriale.

Resultatene synes å tyde på at det er to hovedtyper av premiss-modulatører, illustrert på figur 8. Det øverste preparatet viser den ekstenderte erektile form med spikes and waves. Vi legger merke til avstivningen med fremmed materiale i form av en knappenål. Dette gir en inklinasjon mot de store høyder og et totalinntrykk av professoralt preg. Denne typen bekrefter således et aksiom av forfatteren Didrik From som sier: «Det er mer mellom himmel og jord enn andre steder.»

Det andre preparatet på samme figur illustrerer den kontraktile, sirkulatoriske type, og grad en av hensiktsmessighet ved en slik cyklotym pyknisk form fremgår direkte av preparatets uttrykk.

Hovedprinsippene for den premissmodulator som nå er ferdig konstruert og fremstilt som prototyp er at man nå er i stand til å programmere inn ferdige konklusjoner og kort etter få ut de riktige, tilpassede premisser i korrekt rekkefølge i samsvar med von Jenck's lov.
Figur fjernet av hensyn til opphavsrett. Se artikkelens utgave på papir for fullstendig versjon

Fig. 8. Hovedtyper av premissmodula-

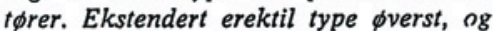
kontraktil pyknisk type nederst.

Figur fjernet av hensyn til opphavsrett. Se artikkelens utgave på papir for fullstendig versjon

Fig. 9. Kontrollert skånsom premissmodulering på professornivå.
Figur fjernet av hensyn til opphavsrett.

Se artikkelens utgave på papir for fullstendig versjon 
Figur fjernet av hensyn til opphavsrett. Se artikkelens utgave på papir for fullstendig versjon

Fig. 12.

×But the computer said you'd sleep with me.,

Heretter skulle det således ikke by på noen problemer til enhver tid å begrunne hva man mener. Dessuten vil man ved å eliminere prøve- og feilemetoden hurtig og sikkert kunne mene hva som ventes av en i en bestemt stilling eller situasjon.

Påliteligheten ved det nye anlegget har vært testet ved hjelp av matematisk statistikk. Under innkjøringen oppe på Blindern er releer og forsterkere trimmet ved hjelp av en hendig liten matematisk formel hvor y er et uttrykk for påliteligheten ved Morality in per cent. Datagrunnlaget skriver seg fra det tidligere omtalte kyllingforsøk.

Det er med dette ganske store og revolusjonerende muligheter som åpner seg. I det kjente tidsskriftet Punch har man allerede gitt uttrykk for hvordan man kan tenke seg å håndtere premissmodulatoriske prosesser på professornivå (fig. 9).

Det er vel riktig å bevare en viss reservasjon. I USA har man jo allerede registrert enkelte feilslag ved date-matching på humant forsøksmateriale ved hjelp av computere (fig. 12). Men på dette felt, der det avgjørende irrasjonelle moment fortsatt er lite utforsket, gjør man vel klokest i å regne med en høy feilmargin uansett hvilken metode man enn velger å bruke. 